\section{Kustamonu Eğitim Dergisi Kastamonu Education Journal}

Mart 2019 Cilt:27 Sayı:2

kefdergi.kastamonu.edu.tr
Başvuru Tarihi/Received: 26.03.2018

Kabul Tarihi/Accepted: 09.08.2018 DOI: $10.24106 /$ kefdergi. 2841

\title{
Uzaktan Öğrenenlerin Sosyal Medya Kullanımlarına Yönelik Bir Araştırma: AöfAnadolum Örneği
}

\section{A Study on The Use of Social Media of Open Education System Students: The Example of AofAnadolum}

\section{Öz}

\author{
Illker USTA ${ }^{1}$, Serap UĞUR², Muhammet Recep OKUR ${ }^{3}$, Gökhan KUŞ
}

Facebook Türkiye'de üniversite öğrencileri arasında en yaygın kullanılan sosyal paylaşım ağı olarak, bireylerin birbirleriyle etkileşim sağladıkları ortamlardan biridir. İlk kez 1960'lı yılların başlarında iletişim araştırmaları için kullanılan, kullanım ve doyumlar yaklaşımı; kullanıcıların aktif olduğunu vurgulayan ve "medya insanlara ne yapıyor" sorusundan çok, "insanlar medya ile ne yapıyor?" sorusuna odaklanarak kullanıcıların bilinçli katılımcılar olduğunu savunmuştur. Kullanımlar ve doyumlar kuramında kullanıcılar iletişime gerekli olduğu için değil gönüllü olduğu için girmektedirler. Bu araştırmada Anadolu Üniversitesi Açıöğretim Sistemi kurumsal Facebook sayfası olan AofAnadolum sosyal medya ortamı, kullanımlar ve doyumlar yaklaşımı bağlamında incelenmiştir. Araştırma betimsel tarama yöntemi ile gerçekleştirilmiştir. Veriler, 3 Şubat 2016-28 Şubat 2017 tarihleri arasındaki Facebook tarafindan sağlanan "sayfa istatistikleri" bölümünden elde edilen verilerle sınırlıdır. Bu çerçevede Açıköğretim sistemi sosyal medya hesabının kullanım durumu çeşitli değişkenler açısından incelenerek takipçilerinin demografik özellikleri, kullanım durumlarındaki değişim ve takipçilerin paylaşımlara gösterdikleri duygusal tepkiler belirlenmeye çalışımıştr. Elde edilen sonuçlar, kurumun sosyal medya ortamını bilgi verme amacıyla kullanmakta olduğunu, takipçilerin ise daha çok enformasyon alma ve destek görme amacıyla kullandığını, takipçilerin sınavlar ve sorular ile ilgili paylaşımlara ilgi gösterdiğini ve tepkilerini bu ortamdan paylaştkklarını ortaya koymuştur.

Anahtar Kelimeler: açık ve uzaktan öğrenme, sosyal medya, uzaktan öğrenen, açıköğretim sistemi

\section{Abstract}

In Turkey, the most widely used as a social networking platform Facebook is one of the medium among college students in which they interact with each other. The use and gratification approach assessed for communication researches for the first time in the early 1960s; it is an approach that advocates users are conscious participants, focusing on the question "what are people doing with the media?" rather than the question "what is the media doing to people", emphasizing that users are active. That is to say, according to the use and gratification theory, users are not volunteering because of communication necessary. According to the use and gratification theory, users are not volunteering because of communication necessary. In this research, it was aimed to examine the social media environment of AofAnadolum which is the institutional Facebook page of Anadolu University Open Education System in the context of use and gratification approach. This study was carried out by descriptive scanning method. The datas are limited from the "page statistics" section provided by Facebook between February 3, 2016 and February 28, 2017. In this framework, the use of the social media account of the Open Education system was examined in terms of various variables that the demographic characteristics of the followers, the change in the usage situation and the emotional reactions of the followers to the sharing were tried to be determined. Results shows that, institutions aim of using social media platform is informing, followers use it more for information and support. A very large proportion of followers are interested in the exams and the sharing of questions and reacting them.

Keywords: open and distance learning, social media, distance learner, open education system

1. Anadolu Üniversitesi, Eskişehir, Türkiye; https://orcid.org/0000-0002-3549-1511

2.Anadolu Üniversitesi, Eskişehir, Türkiye; https://orcid.org/0000-0002-4211-1396

3. Anadolu Üniversitesi, Eskişehir, Türkiye; https://orcid.org/0000-0003-2639-4987

4. Anadolu Üniversitesi, Eskişehir, Türkiye; https://orcid.org/0000-0002-2424-2720

Attf / Citation: Usta, İ., Uğur, S., Okur, M. R., Kuş, G. (2019). Uzaktan Öğrenenlerin Sosyal Medya Kullanımlarına Yönelik Bir Araştırma: AöfAnadolum Örneği. Kastamonu Education Journal, 27(2), 809-822. doi:10.24106/kefdergi.2887 


\section{Extended Summary}

Purpose: Because of the rapid development of technology the traditional mass media have left their places to the new infrastructure of information technology, which is internet infrastructure, are called the social media and the new media. Social media; is an application area that enables sharing of information, ideas and experiences and places the internet world in our life quickly. Today, social media tools are widely used are Facebook, Twitter, Wordpress, LinkedIn, Google, Foursquare, Blogger and Youtube. Facebook, Twitter and Instagram are the most preferred social networks in the world. Turkey, also ranking as the top social media users are located in the world. Although each social media environment has its own characteristics, the media in a general sense called social media have some features. These are participants, openness, mutual communication, community building and linking. The theoretical sub-structure of this research constitutes the approach of use and satisfaction. Uses and satisfaction according to researchers are shaped on the basis that the audience is active and the audience freely chooses the program and the media that will provide the best satisfaction to their needs. In the context of this theory, the demographic characteristics of the users of AOFAnadolum, the official social media account of the Anadolu University Open Education System, and the reactions of the followers to the changes and sharing of usage between 3 February 2016 and 28 February 2017 were examined.

Method: Descriptive scanning method was used in this study. Scanning models are an appropriate model for research that aims to describe the past or present as it exists (Karasar, 2012). In this study, "Facebook" was considered as the corporate social media account and other media were not examined. The data is limited to data from the "page statistics" section provided by Facebook between February 3, 2016 and February 28, 2017.

Findings : The social media environment opened to provide information to students and to provide some student support services has been used by the students in order to receive more information and support as appropriate. Between February 2016 and February 2017, a small number of people shared both social media experiences and student characteristics. For the first time, it has been observed that a very large proportion of students using such a support environment are generally clustered under the last share, rather than commenting under the relevant share. As the followers has better acquaintance on Open Education System and recognize the characteristics of the corporate social media environment, it is anticipated that as the experience increases, more meaningful comments will be made under the relevant sharing. It is envisaged that the pursuits' interest, needs and expectations will be determined and shared in these issues will enable the social media environment to be used more efficiently. During July 2016 and February 2017, students interacted more intensely than the other months. The reasons of this information are the facts that students should pay more attention and attention to the exams and the sharing of questions. It is envisaged that the pursuits' interest, needs and expectations will be determined and shared in these issues will enable the social media environment to be used more efficiently. It can be said that the types of page sharing should be diversified in order to provide satisfaction in the dimensions of entertainment and socialization which are highlighted by the usage and satisfaction approach. It has been determined that the increase in likelihood of the relevant social media account takes place after the sending of the SMS, which is the other information providing medium of the institution. It is anticipated that as the habit of using the social media environment decreases SMS sharing and social media environment becomes a very important information platform. It is envisaged that a different support environment that the institution will form will evolve more in terms of social interaction and information sharing by avoiding the supportive use of the existing social media environment. The experience of the inexperienced at the point of understanding the purpose of sharing the social media environment of the followers reflected on their behavior. They share the liking of meeting the expectation of the agenda, and the "Angry" expression of the shares that are not related to the subject they expect. 


\section{Giriş}

Geleneksel kitle iletişim araçları, yerini teknolojinin hızla gelişmesiyle sosyal medya, yeni medya vb. isimlerle anılan, alt yapısı internet olan enformasyon teknolojisinin yeni araçlarına bırakmıştır.

İnternetin gelişimi ve Web 2.0 teknolojilerinin ortaya çıkışı ile birlikte, tüketen konumundaki bireyler istedikleri içerik türlerinde üretim yaparak yayımlama ve paylaşabilme imkânına erişmiştir. Bu paylaşım ortamları sosyal medya olarak anılmaktadır. İnternet, sosyal medya ile kendi içinde altın çağını yaşamaktadır (Solmaz, Tekin, Herzem ve Demir, 2013).

Sosyal medya; bilgi, fikir ve deneyimlerin paylaşımına olanak sağlayan ve internet dünyasını hızla hayatımıza yerleştiren bir uygulama alanıdır. Kullanıcılara enformasyon, düşünce, ilgi ve bilgi paylaşma imkânı tanıyarak, karşılıklı etkileşim yaratan çevrimiçi araçlar ve web siteleri için ortak kullanılan bir terimdir (Kaplan ve Haenlien, 2010; Sayımer, 2008:123; Weinberg, 2009:1). Sosyal medya; çeşitli çevrimiçi bloglar, tüketici forumları, tartşma panelleri, sohbet odaları, tüketiciden-tüketiciye e-postaları, tüketici ürün veya hizmet puanlama siteleri, mobloglar (dijital ses, görüntü film veya fotoğraflar) ve sosyal ağ siteleri gibi bileşenlerden oluşan bir iletişim aracı olarak konumlandırılmaktadır (Mangold ve Faulds, 2009).

Sosyal medya, farklı kullanım alanlarında ve farklı araçlarla gelişmesini sürdürmektedir. Günümüzde yaygın olarak kullanılan sosyal medya araçları; Facebook, Twitter, Wordpress, Linkedın, Google, Foursquare, Blogger ve Youtube'dur. Facebook, Twitter ve Instagram dünyada kullanıcıların en çok tercih ettiği sosyal ağlardır. 2017 yılının Ocak ayı dikkate alınarak www.statista.com web sitesinin oluşturduğu istatistiklere göre; Facebook'un kullanıcı sayısı 1.871 milyar, Twitter'ın 317 milyon ve Instagram'ın ise 600 milyondur (Statisca, 2018). 2017 yılında 239 ülkenin internet, sosyal medya ve mobil araç kullanım istatistiklerinin yer aldığı araştırmada, Türkiye'de 66 milyon (TÜiK, 2018) internet kullanıcısı ve 48 milyon sosyal medya kullanıcısı olduğu belirlenmiştir. Türkiye, sosyal medya kullanıcıları sıralamasında da dünyada üst sıralarda yer almaktadır. Filipinler ve Meksika'dan sonra Türkiye en çok Facebook kullanıcısı, Meksika, Arjantin ve Vietnam'dan sonra en çok YouTube kullanıcısı ve Endonezya'dan sonra en çok Twitter kullanıcısına sahip olan ülkedir (Smartinsight, 2018).

Her yeni mecra kendine özgü iletişim ve etkileşim becerileri ile gelmekte ve kullanıcılarına paylaşım imkânı sunmaktadır. Sosyal medya ortamları paylaşımın oldukça yüksek katılımlı gerçekleştiği ortamlardır. Her ne kadar her sosyal medya ortamının kendine özgü özellikleri olsa da genel anlamda sosyal medya denilen ortamlar bazı özelliklere sahiptir (Mayfield, 2010'dan aktaran Vural ve Bat 2010; Akar, 2010):

- Katılımcılar: Sosyal medya, katılımcıları cesaretlendirir ve paylaşımlara ilişkin her bir kullanıcıdan geri bildirim alır.

- Açıklık: Her ne kadar sosyal medya hizmetlerinin çoğu kathlım ve geri bildirime açık olsa da bilgi paylaşımını, oylamayı ve yorum yapmayı da destekler (Yamamoto ve Şekeroğlu 2014:13).

- Karşılıklı iletişim: Geleneksel medya tek taraflı yayına yönelik olmasına rağmen, sosyal medya karşııılı iletişime imkan tanıyarak etkileşim sağlar.

- Topluluk oluşturma: Sosyal medyada topluluklar oluşturmak mümkündür. Böylelikle aynı ilgilere sahip kullanıcılar sevdikleri fotoğraf, politik değerler, favori TV şovları gibi konularda paylaşımlar yaparak iletişime geçebilirler.

- Bağlantılılık: Sosyal medyada konu ile ilgili farklı siteler, ilgili araştırmalar, farklı sayfalarla bağlantılar kurma yoluyla bağlantılık boyutu kazanmaktadır.

\section{Kullanımlar ve Doyumlar Yaklaşımı}

Alikılıç, Gülay ve Bilbil (2013) çalışmalarında Interactive Advertisement Bureau'nun 2011 yılında gerçekleştirdiği 15 yaş ve üzeri internet kullanıcılarının internet üzerinde yaptıkları aktiviteler konulu araştırma sonuçlarını sunmuş ve Türkiye'de internet kullanıcılarının \%57.7'lik en fazla oranla interneti arkadaşları ile haberleşmek ve sosyal ağlara katılmak için kullanmakta olduklarını belirtmişlerdir (IAB, 2017). Yine aynı araştırmaya göre, sosyal ağlardan biri olan Facebook Türkiye'de üniversite öğrencileri arasında en yaygın olan sosyal ağ olarak belirtilmektedir. Facebook'un üniversite öğrencileri arasında bu denli yaygın kullanılmasının birçok nedeni bulunmaktadır. Aslında insan davranışının sebebini anlamak için bireyi bu davranışa iten sebeplere bakmak önemlidir.

Yıldız ve Demir'in (2016) üniversite öğrencilerinin internet ve sosyal medya kullanım amaçlarını belirlemeye dönük yaptıkları araştırmada, internet ve sosyal medyayı kullanım amaçlarını ölçmek için nominal ölçek tipi kullanmışlardır. Yapılan araştırmaya göre sosyal medyayı öğrencilerin en çok zaman geçirmek için kullandıkları ve sırayla sohbet, arkadaş takibi, kendini tanıtma, oyun oynama ve arkadaşlık kurmak için kullandıkları belirlenmiştir. 
Aydın (2016) büyük bir çoğunluğu 16-24 yaş aralığın da olan, 4000 den fazla öğrenciye çevrimiçi ortamda anket uygulanarak gerçekleştirilen ve Açıköğretim Fakültesi öğrencilerinin sosyal medya kullanım alışkanlıklarını belirlemek amacıyla bir araştırma gerçekleştirmiştir. Araştırmada hem kadın hem de erkek öğrencilerin sosyal ağlara girme nedenlerinin başında arkadaşlarıyla iletişim kurma isteklerinin olduğu görülmüştür. Bunu sırasıyla yeni bilgiler edinme, araştrrma yapma, fotoğraf paylaşma ve eğitim alma gibi nedenler takip etmektedir.

Bir diğer araştırma da ise, üniversite öğrencilerinin, sosyal medyayı neden kullandığı, kullanımlar ve doyumlar yaklaşımı bağlamında incelenmiştir. Sosyal medya kullanan, Yeditepe Üniversitesi İletişim Fakültesi öğrencileri ile gerçekleştirilen odak grup görüşmelerinde, gençlere, sosyal medya kullanım tercihlerine, sıklıklarına, nedenlerine, paylaşım içeriklerine ve erişim şekillerine yönelik sorular yöneltilmiştir. Araştırmada, öğrencilerin, sosyal medya araçlarından Facebook, Twitter ve Instagram kullanımlarına odaklanılmıştr. Bu niteliksel araştırma kapsamında, öğrencilerin Facebook ve Twitter kullanımlarının azaldığı, Facebook'u sosyal etkileşim, bilgi edinme, Twitter’ı habere ulaşma, düşüncelerinin ifadesi ve Instagram'ı da ağırlıklı olarak eğlence ve zaman geçirme amaçlı kullandıkları belirlenmiştir (Üçer, 2016).

Bedir (2016) tarafindan yapılan ve sosyal medya kullanımının üniversite öğrencilerinin akademik başarılarına ve tutumlarına etkisinin belirlenmeye çalışıldığı araştırmada, sosyal medyayı kullanan öğrencilerin hangi sıklıkla ve hangi amaçla kullandıkları incelenmiş, öğrencilerin sosyal medyayı kullanım amaçlarına göre, en çok gündemi takip etmek için kullandıkları bunu sırasıyla fotoğraf/video paylaşma ve sohbet etmek için kullandıkları görülmüştür. En az ise interaktif oyunlar oynamak amacıyla kullandıkları tespit edilmiştir.

Sezgin vd. (2011) çalışmasında, Facebook'u kullanma sebebi olarak en fazla arkadaşları ile sohbet etmek ve güncel olayları takip etmek amacıyla kullandıklarını belirtmişlerdir. Vural ve Bat (2010) sosyal medya uygulamalarını ise genellikle zaman geçirmek ve çevrimiçi sohbet amacıyla kullanıldıklarını belirtmektedirler.

Küçükali (2016) tarafindan Atatürk Üniversitesi IiBF ÇEKO bölümünde öğrenim gören öğrencilerin sosyal medya kullanımlarına ilişkin yapılan araştırma da, araştırmaya katılan üniversite öğrencilerinin tamamına yakınının sosyal medyayı eğlenmek ve rahatlamak için kullanmakta oldukları belirlenmiştir.

Erkek (2016) tarafindan sosyal medyanın kamu idare ve kuruluşları tarafindan doğru kullanımı ile ilgili bilgiler sunmak ve yönetişim ilkeleri kapsamında sosyal medyanın kamu yönetimi üzerindeki etkisini Sağlık Bakanlığı sosyal medya uygulamalarını inceleyerek ortaya koymak amacıyla bir çalışma yürütülmüştür. Nitel araştırma yönteminin kullanıldığı araştırmada, Sağlık Bakanlığı'nın Facebook ve Twitter adreslerindeki paylaşımları ve Sağlık Bakanlığı sosyal medya uzmanı ile yapılan röportajdan elde edilen bilgiler kullanılmaktadır. Çalışmada ayrıca Gençlik ve Spor Bakanlığı'nın Facebook ve Twitter hesapları ve bu hesaplardaki paylaşımları Sağlık Bakanlığı'nın sosyal medya hesaplarındaki paylaşımları ile kıyaslanmaktadır. Araştırmada Sağlık Bakanlığı sosyal medya uygulama örnekleri doğru ve etkili bir şekilde kullanıldığında Facebook ve Twitter ortamları kamu kurumları için tanıtım, halkla ilişkiler, eğitim ve bilgilendirme, kriz yönetimi gibi pek çok alanda kamu hizmetlerini destekleyici bir iletişim aracı olarak kullanılabildiği belirlenmiştir.

İlk kez 1960'lı yılların başlarında iletişim araştırmaları için kullanılan kullanım ve doyumlar yaklaşımı; izleyicinin (katılımcı, takipçi) aktif olduğunu vurgulayan bir yaklaşımdır (Severin ve Tankard, 2001). Katz'da (1959) bu yaklaşımı savunmuş ve "medya insanlara ne yapıyor" sorusundan çok, "insanlar medya ile ne yapıyor?" sorusuna odaklanmıştr. Bu kuram medya ve izleyici (dinleyici, katılımcı, takipçi) arasındaki ilişkiye olan bakış açısını değiştirerek, onların daha aktif olduğunun kabul edilmesini sağlamakla birlikte, medya kullanımının (tüketiminin) kullanıcı (tüketici) tarafindan bilinçli bir biçimde gerçekleştirdiğini öngörür. Katılımcılar ihtiyaçlarının bilincinde ve ona göre ortam seçme ve seçtikleri ortamda bulunma davranışı göstermektedir. Kullanımlar ve doyumlar kuramında kullanıcılar iletişime gerekli olduğu için değil gönüllü olduğu için girmektedir (Erdoğan ve Alemdar, 2005).

Araştırmacılara göre kullanımlar ve doyumlar çalışmaları, izleyicinin etkin olduğu ve izleyicinin kendi gereksinimlerine en iyi doyumu sağlayacak medyayı ve programı özgürce seçtiği temelinde şekillenmektedir.

İzleyici, medyanın yayınladıklarına karşı edilgen değil, etkindir. Bu içerikleri seçerek alır. Örnek olarak Anadolu Üniversitesi Açıköğretim Sistemi kurumsal sosyal medya hesabı (facebook.com/AOFAnadolum) incelemelerinde takipçilerin paylaşımlar noktasında seçici davrandığı görülmektedir. Kendi ilgi ve ihtiyaçları doğrultusunda paylaşımlara yanıt verdiği görülmektedir. İzleyici kendi gereksinimlerine en iyi doyumu sağlayacak medyayı ve programı özgürce seçer. Medya yapımcısı programın kullanım biçimlerinin farkında olmayabilir ve farklı izleyiciler aynı programı farklı gereksinimleri gidermek amacıyla kullanabilirler (Fiske, 2003; 199). AÖFAnadolum sosyal medya hesabının takipçilerce hangi amaçla kullanıldığı ayrı bir araştırma konusu olsa da değerlendirmeye alınan veriler neticesinde takipçilerin bir kısmının tamamen bilgi alma, bir kısmının sisteme geri bildirim verme gibi çeşitli amaçlarla takipte olduğu söylenebilir. 
Olgunlaşmaya başladığı tarihten itibaren kullanım ve doyumlar yaklaşımı bağlamında kitle iletişim araçları üzerine yapılan birçok araştırma bulunmaktadır. Kullanımlar ve doyumlar kuramıyla ilgili araştırma yapanlar, çalışmalarıyla ilgili olarak izleyicinin gereksinimlerini sınıflandırmak ihtiyacı duymuşlardır. Bu araştırmalarda ortaya çıkan kullanım tercihleri ve doyumlarına ilişkin yapılan bazı sınıflandırmalar Tablo 1. de gösterilmektedir.

\section{Tablo 1. Kitle iletişim ortamları kullanım tercihleri}

\begin{tabular}{|c|c|c|c|c|}
\hline \multirow{3}{*}{$\begin{array}{c}\text { YIl } \\
1949\end{array}$} & \multirow{2}{*}{$\begin{array}{l}\text { Araştırmacı } \\
\text { Berelson }\end{array}$} & \multirow{2}{*}{$\begin{array}{l}\text { Mecra } \\
\text { Gazete }\end{array}$} & \multicolumn{2}{|l|}{ Sınıflandırma } \\
\hline & & & Kamusal bilgi alma ve yorumlama & Sosyal prestij sağlama \\
\hline & & & Günlük yaşamı sürdürme aracı & Sosyal kontak kurma \\
\hline & & & Dinlenme & Günlük rutin faaliyetler \\
\hline 1961 & Scramm ve Parker & TV & Anlık ve ertelenmiş tatmin & \\
\hline 1071 & Weiss & TV & Bilgisel/eğitimsel & \\
\hline 171 & & & Fantazyacı/Kaçışcı & \\
\hline & Blumler, McQuail ve & TV & Oyalanma (Eğlence) & Kişisel kimlik \\
\hline $19 / 2$ & Brown & & Kişisel ilişkiler & Gözetim \\
\hline & Katz, Gurevitch ve & TV & Bilişsel ihtiyaç & Sosyal bütünleşme \\
\hline 1973 & Haas & & Duygusal ihtiyaç & Gerçeklerden kaçma \\
\hline & & & Kişisel bütünleşme & \\
\hline & Greenberg & TV & Alışkanlık & Unutma/Gerçeklerden uzaklaşma \\
\hline 1974 & & & Uyarılma/Bilinçlenme & Zaman geçirme \\
\hline & & & Arkadaşlık & \\
\hline & Mcleod ve Becker & TV & Gözetim & Heyecan \\
\hline 1974 & & & Oy için rehberlik & Destek \\
\hline & & & Beklenen iletişim & \\
\hline & Rubin ve Rubin & TV & Bilgi & Uygunluk ve rahatlık \\
\hline 1982 & & & Masrafsız ve ücretsiz olma & Arkadaşlık \\
\hline & & & Eğlence & \\
\hline & Bantz & TV & Gözetim & Gözetleme \\
\hline 1982 & & & Arkadaşlık & Toplumsal Kaynak \\
\hline & & & Örnek oluşturma & Eğlence \\
\hline & Rafaeli & Elektronik Bildiri & Oyalanma & \\
\hline 1986 & & Panosu & Boş zaman değerlendirme & \\
\hline & & & Eğlence & \\
\hline & Rubin ve Bantz & Video & Kütüphane & Çocuk denetimi \\
\hline 1987 & & & Kendi video ve müziğini kaydetme & Zamanı değiştirme/Atlatma \\
\hline & & & Kiralama & Sosyalleşme \\
\hline 1994 & Dimmick, Sikand ve & Telefon & Sosyallik/Toplumsallık & Toplumsal koordinasyon \\
\hline 1994 & Patterson & & Araçsallık & Güven verme \\
\hline & Leung ve Wei & Cep Telefonu & Moda & Hareketlilik \\
\hline & & & Statü & Anında erişim \\
\hline 2000 & & & Etkileme & Araçsallık \\
\hline & & & Sosyallik & Güven verme \\
\hline & & & Rahatlama & \\
\hline & Ferguson ve Perse & İnternet & Eğlence & Toplumsal enformasyon \\
\hline 2000 & & & Zaman geçirme & Öğrenme \\
\hline & & & Rahatlama/Kaçış & \\
\hline & Parker ve Plank & İnternet & Arkadaşıı & Gözetim ve Eğlence \\
\hline & & & Toplumsal etkileşim & Rahatlama ve Kaçış \\
\hline
\end{tabular}




\begin{tabular}{|c|c|c|c|c|}
\hline YII & Araştırmacı & Mecra & Sınıflandırma & \\
\hline \multirow{3}{*}{2000} & \multirow[t]{3}{*}{ Papacharissi ve Rubin } & \multirow[t]{3}{*}{ Internet } & Kişiler arası fayda & Uygunluk/Elverişlilik \\
\hline & & & Zaman geçirme & \multirow[t]{2}{*}{ Eğlence } \\
\hline & & & Enformasyon arayışı & \\
\hline \multirow{3}{*}{2006} & \multirow[t]{3}{*}{ Sherry vd. } & \multirow[t]{3}{*}{ Video oyunları } & Rekabet & \multirow{3}{*}{$\begin{array}{l}\text { İlgi çekicilik } \\
\text { Kurgu/Düş }\end{array}$} \\
\hline & & & Meydan okuma & \\
\hline & & & Toplumsal etkileşim & \\
\hline & \multirow[t]{3}{*}{ Vivien } & & Gözetim & \\
\hline \multirow[t]{2}{*}{2007} & & & Sosyalizasyon & \\
\hline & & & Eğlence & \\
\hline \multirow{2}{*}{2007} & \multirow[t]{2}{*}{ Dominick } & & Bilme & Sosyal fayda \\
\hline & & & Eğlence & Geri çekilme/izleme \\
\hline \multirow{2}{*}{2007} & \multirow[t]{2}{*}{ Ray } & \multirow[t]{2}{*}{ Sosyal medya } & Eğlence & Oyalanma \\
\hline & & & Gözetim & Sosyalleşme \\
\hline \multirow{3}{*}{2007} & \multirow[t]{3}{*}{ Nyland ve Near } & \multirow[t]{3}{*}{ Facebook } & Yeni insanlarla tanışma & \multirow{3}{*}{$\begin{array}{l}\text { Toplumsal enformasyon } \\
\text { edinme }\end{array}$} \\
\hline & & & Eğlenme & \\
\hline & & & İlişkileri sürdürme & \\
\hline \multirow{5}{*}{2009} & \multirow[t]{5}{*}{ Fragger } & \multirow[t]{5}{*}{ Facebook } & Eski bağları tekrar kurma ve güçlen- & \multirow{5}{*}{$\begin{array}{l}\text { Mecra amaçlı kullanım } \\
\text { Toplumsal karşılaştırma Kıyas } \\
\text { Pazar ortamı }\end{array}$} \\
\hline & & & dirme & \\
\hline & & & Toplumsal enformasyon & \\
\hline & & & Karşılıklı bağlantı & \\
\hline & & & Cinsel çekicilik & \\
\hline \multirow{3}{*}{2011} & \multirow{3}{*}{$\begin{array}{l}\text { Smock, Ellison, Lampe } \\
\text { ve Wohn }\end{array}$} & \multirow[t]{3}{*}{ Facebook } & Sosyal etkileşim & Eğlence \\
\hline & & & Zaman geçirme & \multirow[t]{2}{*}{ Rahatlama } \\
\hline & & & Enformasyon paylaşımı & \\
\hline
\end{tabular}

(Tablo 1'deki sınıflandırmalar Küçükkurt vd. 2009 ve Alikılıç vd. 2013'deki makalelerinden derlenmiştir. )

Tablo 1'de görüldüğü gibi, kuramın fikir olarak ilk kez ortaya atıldığı tarihten itibaren günün teknolojik materyalleri üzerine birçok çalışma yapılmıştr. Gazete, radyo, televizyon, telefon, elektronik bildiri panosu, video, video oyunları, internet, sosyal medya ve özelde Facebook kullanıcıları üzerine yapılan araştırmalar göstermektedir ki; ontolojik bağlamda insanların çoğunlukla özgür iradelerine göre davrandıkları ve tercih sebebi oluşturarak buna bağlı doyum elde ettikleri düşünülmektedir. Genel olarak hemen hepsinde bilgi/enformasyon edinme, eğlence ve sosyalleşme maksatı kullanımlara rastlanmaktadır.

\section{Kamusal Alanda Sosyal Medya Kullanımı}

Bireylerin ve kurumların dijital dönüşüme uyumu, devletlerin de bu dönüşüm karşısında kayıtsız ve yarının bilgi ve inovasyon toplumuna hazır olmak için her zamankinden daha etkili ve yetkin bir şekilde çalışmasını sağlamaktadır. Bu dönüşüm içerisinde Türkiye'nin e-devlet politikaları zaman içerisinde küresel ölçekli dijital dönüşüm ve kamu yönetimi reform çalışmaları doğrultusunda önemli değişikliklere uğramış ve kamu kurum ve kuruluşlarının kurumsal süreçlerinin elektronik ortama taşınması çerçevesinde vatandaş odaklı e-dönüşüm, sosyal ağlar, yönetişim ve şeffaflık ile hesap verilebilirlik kavramları ile tüm paydaşlar ve devlet ilişkileri yeniden tanımlanmaya başlanmıştı (UDH, 2018).

Bu süreçte katılımcı ve bütüncül bir yaklaşım izlenmesinde kamu kurumlarına büyük bir rol düşmektedir. Bu rolün çoğunluğu da vatandaş ve kamu kurumları arasında bir köprü görevi görmeye başlayan sosyal medya platformlarında yer alan kurumsal hesaplar tarafindan yerine getirilmektedir. Sosyal medya araçlarının kamu kurumları tarafindan yaygın bir şekilde kullanılmaya başlanmasıyla etkileşimli bilgi ve hizmet sunumu gerçekleşmektedir (UDH, 2018).

Tablo 2. Bakanlıklara ait sosyal medya kullanım durumları 


\begin{tabular}{lll}
\hline Bakanlık & Facebook & Twitter \\
\hline Adalet Bakanlığı & 479 & 194.509 \\
Aile ve Sosyal Politikalar Bakanlığı & 379.420 & 172.288 \\
Avrupa Birliği Bakanlığı & 55.608 & 75.476 \\
Bilim Sanayi ve Teknoloji Bakanlığı & 150.005 & 105,387 \\
Çalışma ve Sosyal Güvenlik Bakanlığı & 62.294 & 87.095 \\
Çevre ve Şehircilik Bakanlığı & 18.184 & 71,078 \\
Dışişleri Bakanlığı & 300.180 & 1.338 .597 \\
Ekonomi Bakanlığı & 17.976 & 7.113 \\
Enerji ve Tabii Kaynaklar Bakanlığı & 96 & 53.907 \\
Gençlik ve Spor Bakanlığı & 422.166 & 235.090 \\
Gıda Tarım ve Hayvancılık Bakanlığı & 70.135 & 57.057 \\
Gümrük ve Ticaret Bakanlığı & 11.036 & 39.889 \\
İçişleri Bakanlığı & 107.927 & 403.742 \\
Kalkınma Bakanlığı & 7.776 & 74.929 \\
Kültür ve Turizm Bakanlığı & 116.832 & 74.335 \\
Maliye Bakanlığı & 2.898 & 83.682 \\
Milli Eğitim Bakanlığı & 70.591 & 237.130 \\
Milli Savunma Bakanlığı & 79.373 & 106.074 \\
Orman ve Su İşleri Bakanlığı & 108.492 & 56.872 \\
Sağlık Bakanlığı & 883.896 & 355.882 \\
Ulaştırma, Denizcilik ve Haberleşme Bakanlığı & 23.306 & 98.069 \\
\hline & & \\
\hline
\end{tabular}

Tablo 2' de, Türkiye'de 10 Mart 2018 itibariyle, sosyal medya kullanıcıları tarafindan takip edilen Bakanlıklara ait takipçi sayıları gösterilmektedir. Burada tüm bakanlıklara ait kurumsal sosyal medya araçlarının belirgin sayıda kişilerce takip edildiği görülmektedir. Kurumlar, kurumsal yapılarının bir parçası olan vatandaşlara sürekli iletişimlerini sağlayacak ortamlara geçiş yapmaktadırlar. Kurumların amaçları doğrultusunda işleyişini sağlamak, bilgi, düşünce alışverişini kolaylaştırmak için gerekli olan kurumsal iletişimlerini dijital dönüşümle gerçekleştirmeyi amaçlamaktadırlar. Anadolu Üniversitesi Açıköğretim Sistemine kayıtlı öğrencilere sosyal medya aracılığıyla erişimi de bu bağlamda değerlendirebiliriz.

\section{Anadolu Üniversitesi Açıköğretim Sistemi}

1982-1983 öğretim yılına İktisat ve İ̧ İdaresi alanındaki iki uzaktan öğretim programı ile başlayan Açıköğretim Sistemi, 1993'te 496 sayılı Kanun Hükmünde Kararname ile günün eğitim gereksinimlerine göre yeniden yapılandırılmış, İktisat ve İşletme Programları dörder yıllık fakültelere dönüştürülmüştür. Açıköğretim Fakültesi de açıöğgretim ile uygulamaya yönelik işleri yapmakla ve ön lisans, lisans, lisans tamamlama ve her türlü sertifika programlarını yürütmekle görevlendirilmiştir (AÖF, 2017). Açıöğretim Fakültesinde 8 lisans, 39 önlisans, İşletme Fakültesinde 5 lisans ve İktisat Fakültesinde 6 lisans programı bulunmaktadır.

\section{Açıköğretim Sistemi Kurumsal Facebook sayfası: AÖFAnadolum}

2016 yılında, öğrencilerle etkileşimi üst düzeye taşımanın bir yolu olarak sosyal medyanın kullanılmasına karar verilmiş ve bu amaçla Açıköğretim Sistemi Facebook sayfası oluşturulmuştur. 3 Şubat 2016 tarihinde düzenlemeleri yapılan sayfanın ilk tanıtımı için sistemde kayıtlı öğrencilere bilgilendirme amacıyla SMS gönderilmiştir. Oluşturulan sayfanın aynı zamanda sistemin görünürlüğünü ve tanınırlığını arttırmayı da sağlayacağı, öğrencilerin bu sayfa aracılığı ile sistemden taleplerini dile getirme, eleştirilerini iletebilme, sorularına ve sorunlarına çözüm bulabilme ve önerilerde bulunabilme gibi imkânlara sahip olacağı öngörülmüştür. Hangi amaçla olursa olsun, ister eğitim, ister sağlık, ister başka bir konuda oluşturulan sosyal medya ortamı, genel sosyal medya ortamı özelliklerini taşıyacağı varsayımıyla şekillendirilir. AÖFAnadolum sosyal medya hesabının benzer düşünceler ile şekillendirilmiş boyutlarına ilişkin bilgiler Tablo 3'te verilmiştir. 
Tablo 3. AÖFAnadolum sosyal medya hesabı boyutları

\begin{abstract}
AÖFAnadolum
Katilımcılar

Açıklık

Sayfada aktif katılımcılar olmakla birlikte, pasif takipçiler de mevcuttur.

Takipçiler sayfada paylaşılan gönderilerin altına yorum yapabilmekte, görsel ya da video ekleyebilmektedir. Takipçilerin kendi gönderilerini oluşturmaları hususunda kısıtlama getirilmiştir.

Karşılıklı iletişim

Takipçiler hem birbirleri ile hem sayfa yönetimi ile karşılıklı iletişim kurabilmektedir.

Topluluk oluşturma

Sayfa takipçileri hâlihazırda bir topluluktur, sayfadan bağımsız grup kurmaları hususunda bir kısıtlama yapılmamıştır.

Bağlantilılık

Takipçiler; dâhil oldukları sistem, öğrencilikle kazandıkları haklar ve ayrıcalıkları, eğitimle ilgili güncel haberler gibi birçok konuda bilgi edinebilmektedir.
\end{abstract}

Facebook bir sosyal paylaşım ağı olarak bireylerin birbirleriyle etkileşim sağladıkları ortamlardan biridir. Etkileşim kurma gerekçesinin altında bir ortamın kullanımı ve bu kullanım neticesinde elde edilen doyum bulunmaktadır.

Bu bilgiler doğrultusunda ve üniversite öğrencilerinin Facebook'u kullanımlar ve doyumlar yaklaşımının hangi boyutlarında tercih ettikleri sorusundan hareketle bu araştırma gerçekleştirilmiştir. Bu araştırma Anadolu Üniversitesi Açıköğretim Sistemi kurumsal Facebook sayfası takipçileri ile sınırlandırılmıştır. Bu çerçevede Açıköğretim Sistemi sosyal medya hesabının kullanım durumu çeşitli değişkenler açısından incelenerek aşağıdaki araştırma sorularına yanıtlar aranmıştr.

- Açıköğretim sistemi kurumsal sosyal medya hesabı takipçilerinin demografik özellikleri nelerdir?

- Açıköğetim sistemi kurumsal sosyal medya hesabının 3 Şubat 2016-28 Şubat 2017 tarihleri arası kullanım durumlarında nasıl bir değişim olmuştur?

- Açıköğretim sistemi kurumsal sosyal medya hesabı paylaşımları ile ilgili takipçilerin duygusal tepkileri nelerdir?

\title{
2. Yöntem
}

Bu araştırma da betimsel tekil tarama modeli kullanılmıştr. Betimsel tarama modeli olayların, varlıkların, grupların, mevcut durum ve özelliklerini kendi koşullarında betimlemeye ve incelemeye çalışan bir araştırma modelidir (Kaptan, 1998: 53). Bu yaklaşımda araştırmaya konu olan durum ya da durumları değiştirme veya etkileme çabası yoktur. Amaç o şeyi doğru bir şekilde gözlemleyip belirleyebilmektir. Asıl amaç değiştirmeye kalkmadan gözlemektir (Karasar,1998, s.79). Tekil tarama modeli ile ilgilenilen olay, madde, birey, grup, kurum, konu vb. birim ve duruma ait değişkenler, ayrı ayrı betimlenmeye çalışılır (Karasar, 1998, s.79). Anadolu Üniversitesi Açıköğretim Sistemine kayıtlı öğrencilerin kurumsal sosyal medya hesabı olan "AÖFAnadolum" Facebook sayfasını kullanımlar ve doyumlar yaklaşımı çerçevesinde hangi boyutlarıyla kullandıklarını incelemek, araştırmaya konu olan durumu olduğu şekliyle göstermek için betimsel tekil tarama modeli kullanılmıştr.

Bu araştırma da Anadolu Üniversitesi Açıköğretim Sistemi sosyal medya ortamlarından sadece "Facebook" ele alınmış olup diğer ortamlar incelenmemiştir. "AÖFAnadolum" sosyal medya hesabı 3 Şubat 2016 tarihinde öğrencilerin kullanımına sunulmuştur. Araştırmanın amaçları, 3 Şubat 2016 tarihinde öğrencilerin kullanımına sunulan kurumsal sosyal medya hesabı olan "AÖFAnadolum” sayfasının bir öğretim yılı içerisinde yani 28 Şubat 2017 tarihine kadar ki dönemde kullanımına ilişkin Facebook tarafından sağlanan "sayfa istatistikleri” bölümünden elde edilen veriler kullanılarak tartışılmıştır. "Sayfa istatistikleri", hedef kitle hakkında demografik veriler ve gönderilere yanıt veren kişi sayısı gibi sayfa performansına ilişkin bilgiler sağlamaktadır. Bu istatistikler sayesinde insanların sayfa ile nasıl etkileşimde bulunduğu, hangi gönderilerin en çok etkileşim sağladığı, hedef kitlenin Facebook'u ne zaman kullandığı görülebilir (Facebook Yardım, 2017).

\section{Bulgular}

Bu çalışmanın amacı bağlamında birinci araştırma sorusu olan "Açıköğretim sistemi kurumsal sosyal medya hesabı takipçilerinin demografik özellikleri nelerdir?" sorusuna ilişkin cinsiyet, yaş ve yerleşim yerlerine göre dağılım aşağıdaki gibidir. 


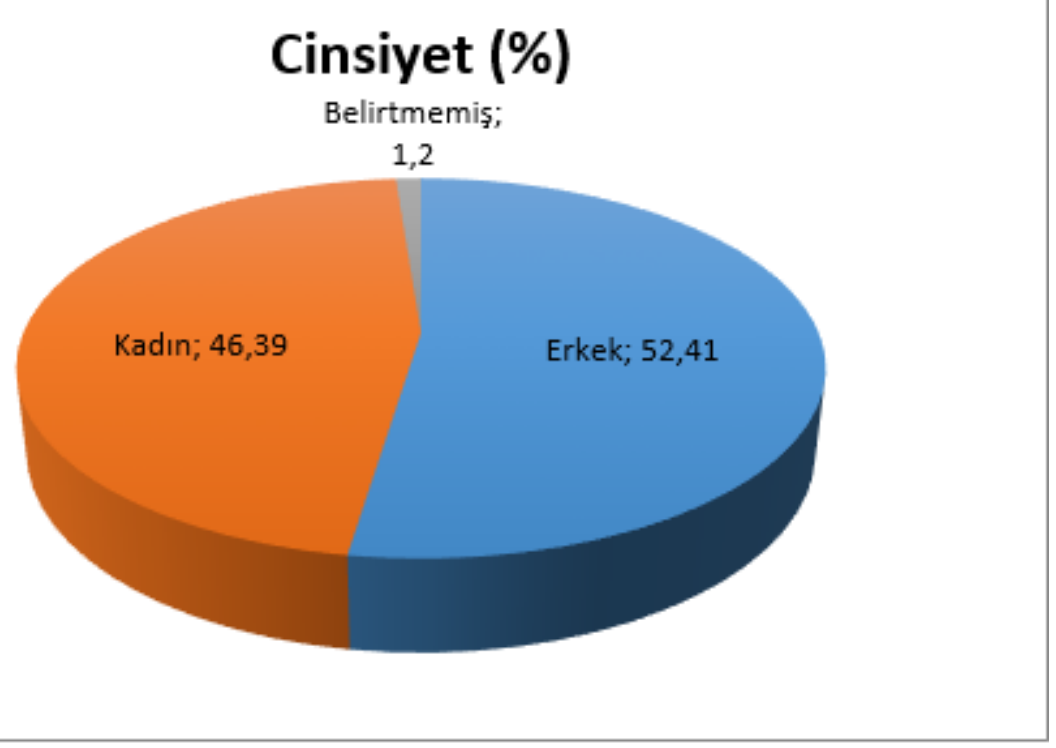

Şekil 1. Sayfa takipçilerinin cinsiyete göre dağılımları

28 Şubat 2017 tarihine kadar sayfa takipçilerinin demografik özelliklerine bakıldığında; \%46'sının kadın, \%52'sinin erkek olduğu görülmektedir. Bu oranların Açıköğretim Fakültesi 2016-2017 öğretim yılı güz ve bahar dönemi kayıtlı öğrenci sayılarının cinsiyete göre dağılımına (Erkek \%56 2, Kadın \%44 \pm 2 ) benzerlik gösterdiği görülmektedir (AÖF, 2017). Buna göre erkek öğrenciler kadın öğrencilere oranla daha fazla sosyal medya hesabını kullanmaktadırlar. Kadın ve erkek takipçilerin yaşlara göre dağılımı da incelenmiş olup Şekil 2'de gösterilmiştir.

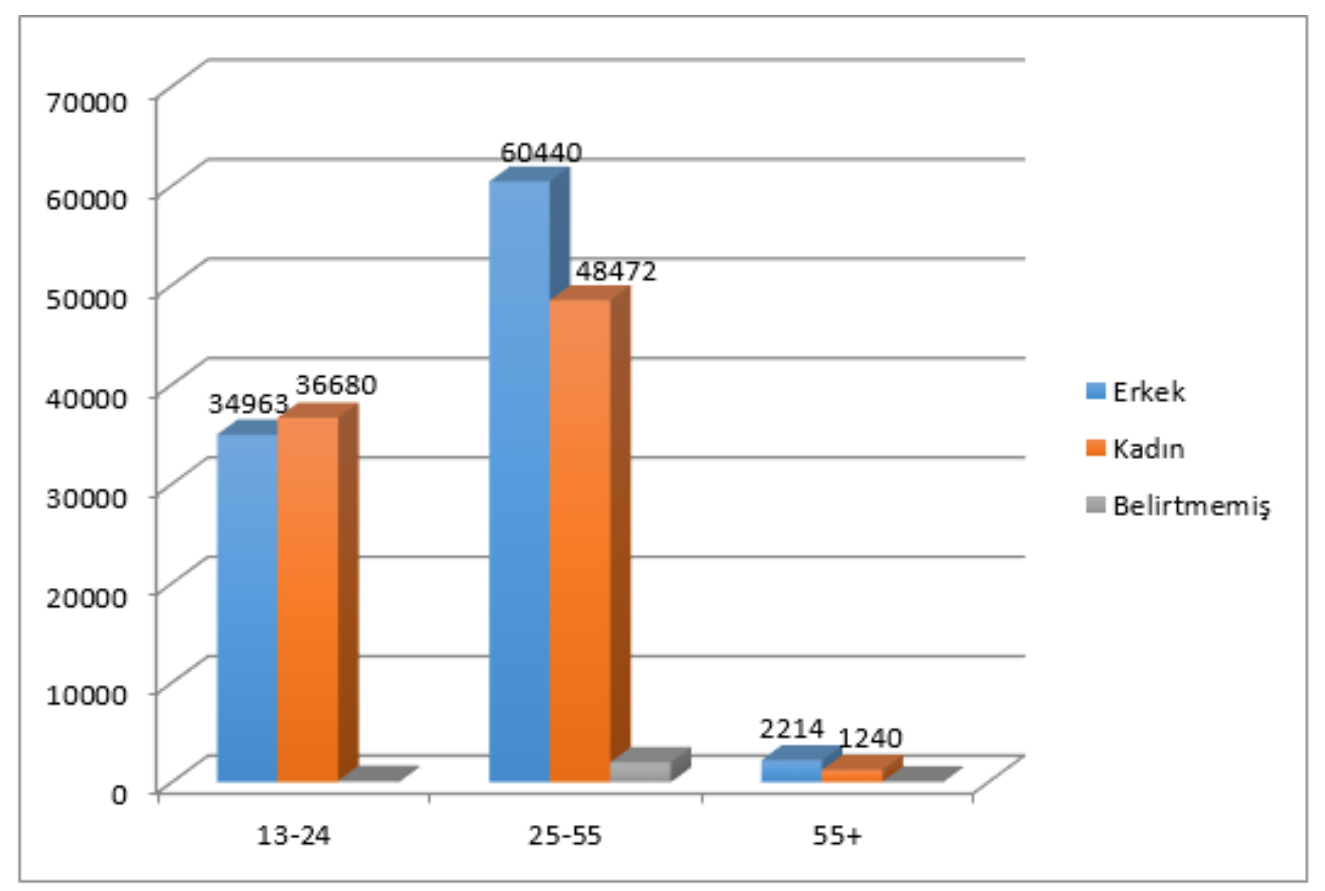

\section{Şekil 2. Kadın ve erkek takipçilerin yaşlara göre dağııımı}

Şekil 2'de, 13-17 yaş arası Anadolu Üniversitesi Açıköğretim sistemine resmi kayıtlı olamayacak yaşta kurumsal sosyal medya hesabına kayıtlı kullanıcıların da olduğu görülmektedir. Bunların, yapılan tanıtım faaliyetleri ve yakın çevre duyumları neticesinde üniversiteye hazırlanan öğrenciler olabileceği, ayrıca sosyal medya hesabı olmayan ebeveynleri için takip eden bireyler olabileceği de düşünülmektedir.

Şekil 2'de görüldüğü gibi 18-24 yaş arası takipçilerin sayısı oldukça fazladır. 18-24 yaş arası ülkemiz koşulları çerçevesinde liseden mezun olabilecek, üniversite okuyan ve üniversiteden mezun olabilecek düzeyde kitleyi göstermek içindir. 
Ayrıca, sayfa takipçilerinin çok büyük bir bölümünün 25-55 yaş arası bireylerden oluştuğu görülmektedir. 25-55 yaş aralığının belirlenmesinin en temel sebebi ülkemiz şartlarında en az üniversite mezunu olup emekli olma yaşına yakın bireyleri kapsayan kitle için durumu göstermektir.

Ayrıca 55 ve üstü yaş takipçilerin de azımsanmayacak sayıda olduğu görülmektedir. 55 yaş ve üstü takipçiler ile ilgili durumu göstermenin en temel sebebi emekli olma yaşına erişmiş veya olmuş katılımcıların dağılımını göstermektir.

Anadolu Üniversitesi, Açıköğretim Sistemiyle Türkiye'nin 81 ilinde 105 bürosu ve yurtdışında birçok ülkede büroları ile bir milyonun üzerinde Türk vatandaşına eğitim hizmeti veren mega üniversitelerden biridir. Kurumsal sosyal medya hesabının bu ülkelerde ve yurtiçi şehirlerde ne kadar ilgi gördüğüne ilişkin bilgi Tablo 4’te gösterilmektedir.

Tablo 4. Takipçilerin yurtdışı ve Türkiye'deki şehirlere göre dağılım durumu

\begin{tabular}{lclc}
\hline ÜLKE & TAKIPÇi SAYISI & ŞEHIR & TAKIPÇi SAYISI \\
\hline Türkiye & 188.373 & Isstanbul & 42.922 \\
Kıbrıs & 1.300 & Ankara & 23.317 \\
Almanya & 278 & İzmir & 11.871 \\
Azerbaycan & 172 & Antalya & 7.140 \\
ABD & 83 & Bursa & 6.113 \\
Avusturya & 61 & Gaziantep & 5.774 \\
Suudi Arabistan & 52 & Konya & 5.037 \\
Yunanistan & 49 & Eskişehir & 3.301 \\
\hline Fransa & 46 & Diyarbakır & 3.225 \\
Kosova & 40 & Kayseri & 2.790 \\
Irak & 39 & Şanlıurfa & 2.713 \\
Belçika & 38 & Samsun & 2.695 \\
İgiltere & 34 & Mersin & 2.361 \\
Vietnam & 34 & Adana & 2.319 \\
Makedonya & 32 & Kocaeli & 1.805 \\
Hollanda & 28 & Denizli & 1.653 \\
Bulgaristan & 27 & Adana / Uşak & 1.487 \\
Endonezya & 27 & Erzurum & 1.444 \\
Bosna Hersek & 23 & Van & 1.425 \\
İsviçre & 23 & Trabzon & 1.374 \\
Polonya & 22 & Sakarya & 1.346 \\
Mısır & 19 & Balıkesir & 1.249 \\
Romanya & 18 & Kahramanmaraş & 1.210 \\
Afganistan & 15 & Malatya / Kütahya & 1.136 \\
Tayland & Hatay & 1.010 \\
\hline
\end{tabular}

Sayfa takipçilerinin yerleşim yerlerine göre dağılımlarına ilişkin veriler incelendiğinde, takipçilerin çok büyük bir kısmının Türkiye'de olduğu görülmektedir. Açıköğretim Sistemi kurumsal sosyal medya hesabının Türkiye dışındaki takipçilerinin Batı Avrupa, Azerbaycan, Bulgaristan, Kosova, Makedonya, Arnavutluk, Bosna Hersek ve Kuzey Amerika programlarından kaynaklandığı düşünülmektedir.

Açıköğretim Sistemi kurumsal sosyal medya hesabı takipçilerinin Türkiye'de il bazında sıralaması incelendiğinde ise, beş binden fazla takipçinin olduğu iller sırasıyla İstanbul, Ankara, İzmir, Antalya, Bursa, Gaziantep ve Konya olduğu görülmektedir. Bu durum 2016-2017 öğretim yılı büro bazında en kalabalık öğrenci grubuna hizmet eden illerle benzerlik göstermektedir. Eskişehir, Diyarbakır ve Adana gibi büyük ölçekli büroların olduğu yerlerde sosyal medya takipçi sayısının az olması dikkat çekicidir. Tayland, Afganistan, Endonezya, Vietnam ve Irak gibi büro ve sınav merkezlerinin olmadığı yerlerde sosyal medya ortamlarının takip edilmesi ayrıca incelenmesi gereken bir durum olarak düşünülebilir.

Bu çalışmanın bir başka araştırma sorusu olan "Açıköğretim sistemi kurumsal sosyal medya hesabının 3 Şubat 2016 - 28 Şubat 2017 tarihleri arası kullanım durumlarında nasıl bir değişim olmuştur?” sorusuna ilişkin dağılım Şekil 3'te gösterilmektedir.

| Kastamonu Eğitim Dergisi, 27(2), 2019| 


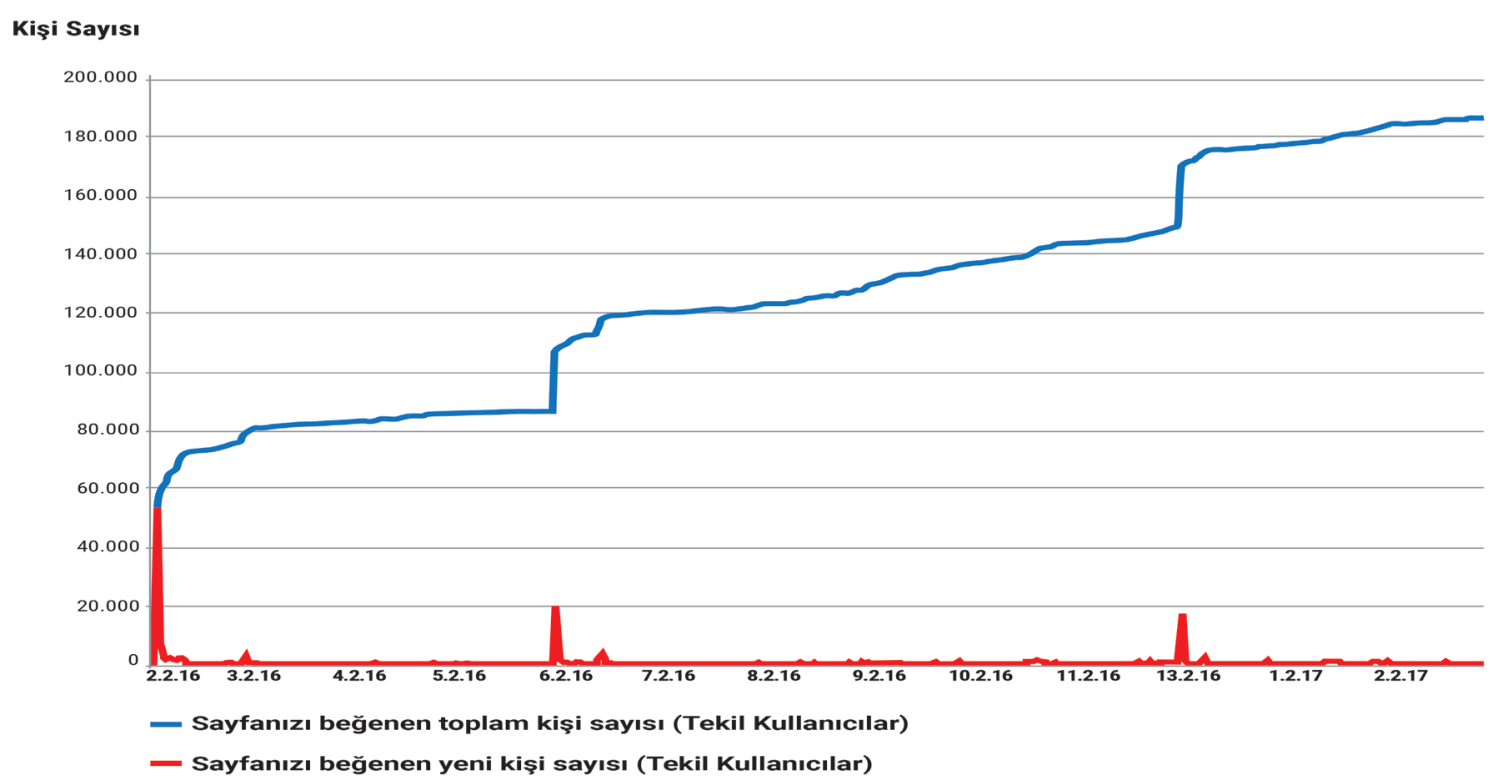

\section{Şekil 3. Beğeni-Artış Dağılımı}

3 Şubat 2016 - 28 Şubat 2017 tarihleri arasında sayfa takipçilerinin artı̧̧ı ve beğeni sayılarındaki değişimi içeren genel grafik Şekil 3'te verilmiştir. Şekil 3 incelendiğinde, günden güne takipçi beğenme sayısının arttğı ve 3 Şubat 2016 tarihinden itibaren öğrencilere aralıklı olarak 3 bilgilendirme amaçlı SMS gönderilmesi ile birlikte sayfanın beğeni sayısında artı̧̧ sağlandığı görülmüştür. Kuramsal açıdan incelenen bu durum öğrencilerin bilgi alma amaçlı sisteme dâhil olup sayfayı takip etmeye başladıklarını göstermektedir. İlk mesaj 03.02.2016 tarihinde gönderilmiş olup bu mesajda sayfanın açıldığına dair bilgilendirme yapılırken, 02.06.2016 tarihinde atılan ikinci mesajda öğrencilere sayfa aracılığı ile güncel bilgiler edinebileceği belirtilmiş, 02.12.2016 tarihinde atılan üçüncü mesajda ise sayfayı takip ederek sınav sonuçlarını ilk öğrenen olunabileceği vurgusu yapılmıştır.

Bilgilendirme SMS'lerinin gönderimleri öncesi ve sonrası takipçi sayılarına ait veriler Şekil 3'te kırmızı çizgi ile gösterilmiştir. SMS'ler sistemde kayıtlı 1 milyonun üzerinde öğrenciye gönderilmiştir. Gönderilen her SMS'ten sonra takipçi sayılarında 25.000 civarı artı̧ olduğu görülmektedir. Bu sayılar beklentinin altındadır. Bunun sebebinin Facebook'un her SMS sonrası takipçi/beğenen artş̧ 25.000-30.000 bandını geçtiğinde yeni beğenileri ve takipleri engellemesi olduğu düşünülmektedir.

Sayfa açıldı̆̆ı andan itibaren sayfadaki gönderilerle ilgili yapılan yorumlar, paylaşııma durumları ve sayfaya bırakılan ifadelerin dağılımı incelendiğinde Şekil 4'deki grafiğe ulaşılmıştır.

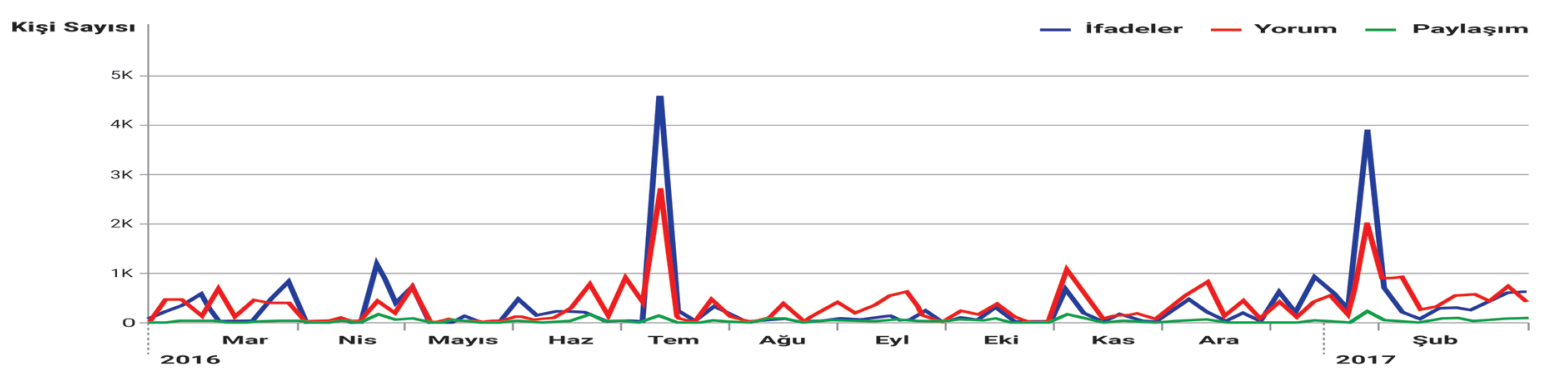

Şekil 4. Gönderilere bırakılan ifadeler, yorumlar ve paylaşılma durumları

Ortaya çıkan bu grafiğe göre, takipçilerin en fazla gerçekleştirdikleri eylemin paylaşımlara ifade bırakmak olduğu söylenebilir. Paylaşımlara yorum yazmak ifade verme eylemini takip etmektedir. Takipçilerin sayfa gönderilerini paylaşma eylemini çok nadir yaptıkları söylenebilir. Sayfa takipçilerinin yoğun paylaşım yapacakları öngörülerek, takibinin zor olması ve yanlış bilgilendirmenin engellenmesi için ziyaretçi gönderilerine kapatılmıştır.

Buna göre, Temmuz ve Ocak aylarında sayfaya bırakılan ifadelerin tepe noktaya ulaştı̆ı görülmektedir. Bunun sebebi, Şubat ayında sınav belgeleri ve sonuçları ile ilgili paylaşımın olması, Temmuz ayında ise mezuniyet ile ilgili paylaşım- 
ların olmasındandır. Buradan takipçilerin sınavlarla ve mezuniyet ile ilgili yapılan paylaşımlara daha çok ilgi gösterdikleri söylenebilir.

Çalışmanın bir diğer araştırma sorusu olan "Açıköğretim sistemi kurumsal sosyal medya hesabı paylaşımları ile ilgili takipçilerin duygusal tepkileri nelerdir?" kapsamında takipçilerin sayfa gönderilerine bıraktkları ifadeler incelenmiştir. Elde edilen sonuç Şekil 5'te verilmiştir.

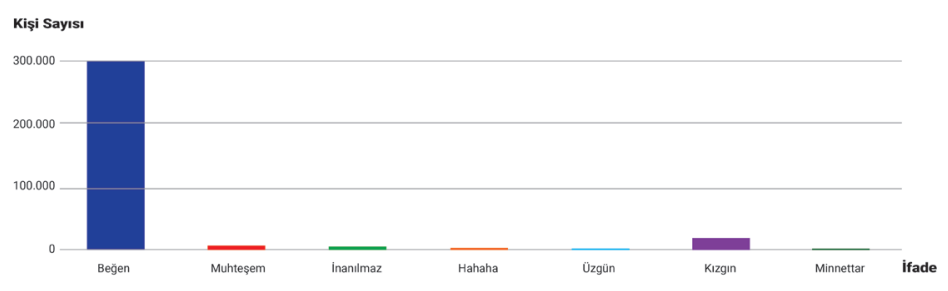

\section{Şekil 5. Sayfaya bırakılan ifadelerin genel dağılımı}

Şekil 5 incelendiğinde, öğrencilerin yapılan paylaşımlara "Muhteşem" ve "Kızgın” ifadelerini bırakanlar olmakla birlikte daha çok "Beğen" ifadesinin (298 Bin) bırakıldığı görülmektedir. Bu durum, sayfa takipçilerinin genel olarak gönderilerle ilgili olumlu izlenime sahip oldukları şeklinde yorumlanabilir.

Özelde ise kurumsal paylaşımlara takipçilerin vermiş oldukları tepkilerde aylık dönemde dağılım çeşitlenmektedir. Dağılım Şekil 6’de gösterilmektedir.

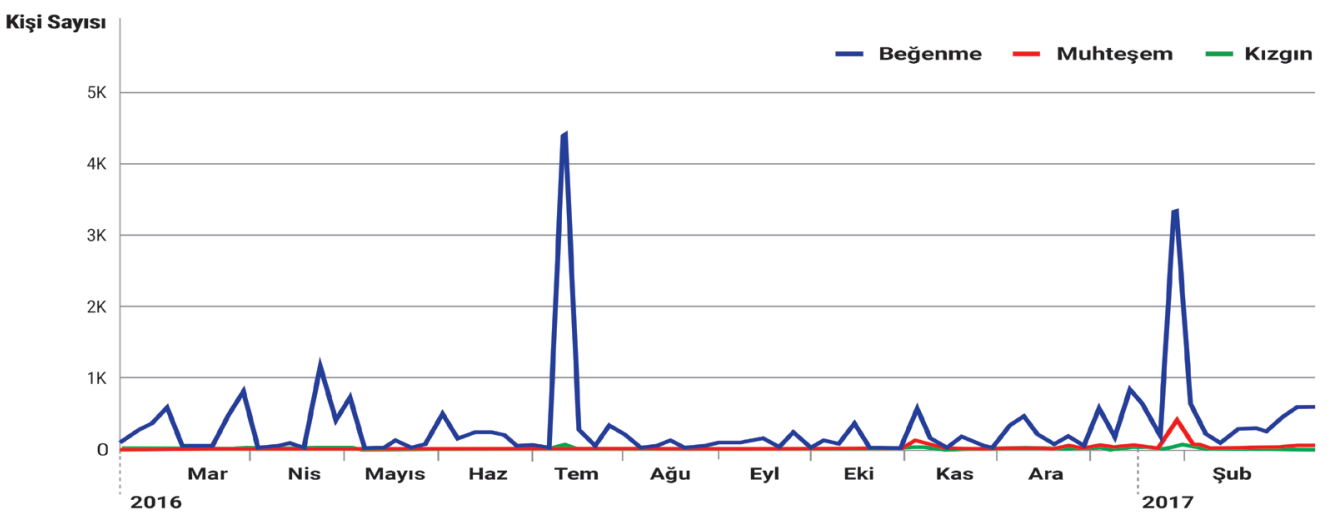

Şekil 6. Sayfaya bırakılan ifadelerin aylık dağılımı

Şekil 6'da görüldüğü gibi, katılımcıların özellikle Temmuz ve Şubat aylarında yapılan paylaşımlara ilişkin yoğun etkileşim kurdukları görülmektedir. Diğer aylarda ise nispeten düşük seviyede bir etkileşimin olduğu belirlenmiştir. Daha önce değinildiği gibi Şubat ve Temmuz aylarındaki sınav ve mezuniyet temalı paylaşımlar yoğun ilgi görmektedir.

Sayfada paylaşılan gönderilerin takipçiler tarafindan erişim durumları incelendiğinde ise bazı paylaşımların diğerlerinden daha fazla ilgi çektiği görülmektedir. Tablo 4'de sayfa takipçilerinin gönderilere ilişkin etkileşim durumları verilmiştir. Buna göre en fazla görüntülenen gönderilere bakıldığında; sınav sorularının yayınlanması, yüz yüze dersler ve Açıköğretim Sistemi faaliyetleri gibi farklı konulardaki paylaşımlar oldukları görülmektedir. Gönderi erişimlerinin içeriklere göre dağılımına ilişkin veriler Tablo 5'deki gibidir. 
Tablo 5. Gönderi erişimlerinin içeriklere göre dağılımı

\begin{tabular}{|c|c|c|c|}
\hline Yayınlanma & Gönderi & Erişim & Etkileşim \\
\hline \multirow[t]{2}{*}{ 18.04.2016 (13:57) } & \multirow[t]{2}{*}{ Sorular https://ekampus.anadolu.edu.tr adresinde! } & \multirow[t]{2}{*}{$199,5 K$} & $80,2 \mathrm{~K}$ (Olumlu) \\
\hline & & & 4,6K (Olumsuz) \\
\hline \multirow[t]{2}{*}{ 08.04.2016 (17:55) } & \multirow[t]{2}{*}{ Sınav giriş belgeleri yayımlandı. https://aof.anadolu.edu.tr } & \multirow[t]{2}{*}{$325,7 \mathrm{~K}$} & 152,6K (Olumlu) \\
\hline & & & 7,4K (Olumsuz) \\
\hline \multirow[t]{2}{*}{ 21.10.2016 (18:12) } & \multirow{2}{*}{$\begin{array}{l}\text { Yüzyüze verilen dersler } 22 \text { Ekim'den } 13 \text { Ocak’a kadar sürecek! https:// } \\
\text { www.anadolu.edu.tr }\end{array}$} & \multirow[t]{2}{*}{$94,8 \mathrm{~K}$} & $11,1 \mathrm{~K}$ (Olumlu) \\
\hline & & & 1,4K (Olumsuz) \\
\hline \multirow[t]{2}{*}{ 23.11.2016 (09:44) } & \multirow{2}{*}{$\begin{array}{l}\text { Sınava Doğru Programı TRT Okul'da! Canlı izlemek için https://www.trto- } \\
\text { kul.com.tr }\end{array}$} & \multirow[t]{2}{*}{$32,7 \mathrm{~K}$} & $1,3 \mathrm{~K}$ (Olumlu) \\
\hline & & & 135 (Olumsuz) \\
\hline
\end{tabular}

Tablo 5'deki verilere bakılarak, takipçilerin daha çok sınavlar ve sorularla ilgili paylaşımlarla ilgilendikleri ve bu bağlamda bakıldığında etkileşimin fazlalaşt̆ğı görülmektedir. Sayfa takipçilerinin çevrimiçi olma durumlarına ait veriler Şekil 7’de gösterilmektedir.

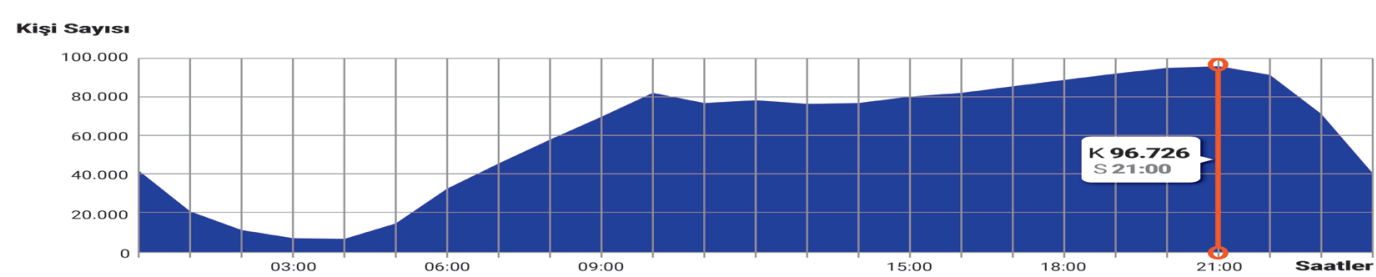

Şekil 7. Takipçilerin aktif oldukları zaman dilimi

Sayfa takipçilerinin çevrimiçi olma durumlarına ait Şekil 7’deki grafik incelendiğinde, takipçilerin sabah 09:00 itibarıyla sayfaya giriş yapmaya başladıkları bununla birlikte en fazla akşam 21:00'de aktif oldukları görülmektedir. Açıköğretim sitemindeki öğrencilerin profiline bakıldığında, çoğunlukla çalışan kesimden öğrenciye sahip olduğu görülmektedir. Bu durum, genel olarak mesai saatlerinde aktif olunması, öğle arasına denk gelen zaman dilimindeki azalma ve akşam saatlerindeki yoğunluğun sebebi olarak düşünülebilir.

\section{Sonuçlar ve Öneriler}

Anadolu Üniversitesi Açıöğretim Sistemi kurumsal sosyal medya hesabı olarak Facebook'un kullanımına ilişkin öğrenci davranışlarının incelenmesi neticesinde; ilgili sosyal medya takipçilerinin \%46'sı kadın, \%52'si ise erkektir. Erkek öğrencilerin kadın öğrencilere oranla daha fazla sosyal medya hesabını kullandıkları görülmektedir. Sayfa takipçilerinin çok büyük bir bölümü 25-55 yaş arası bireylerden oluşmaktadır. Şubat 2016 ve Şubat 2017 tarihleri arasında hem sosyal medya ortamlarını denemek hem de öğrenci özeliklerini tanımlayabilmek açısından az sayıda paylaşımda bulunulmuştur.

Yıldız ve Demir (2016), Bedir (2016), Sezgin vd. (2011), Vural ve Bat (2010) ve Küçükali'nin (2016) yaptıkları araştirma sonuçlarının aksine, öğrencilerine bilgi verme ve bazı öğrencilik destek hizmetlerini sunma maksadıyla açılan kurumsal sosyal medya ortamının öğrenciler tarafindan amaca uygun biçimde yani daha çok enformasyon alma ve destek görme amacıyla kullanıldığı belirlenmiştir. Aydın (2016) ve Erkek'in (2016) yaptı̆ı araştırmaların sonucuna benzer şekilde bu araştırmada da eğitim, bilgilendirme ve yeni bilgiler edinme gibi maksatlarla sosyal medya kullanımının ön plana çıktı̆ı belirlenmiştir.

İlk kez böyle bir destek ortamını kullanan öğrencilerin çok büyük bir oranının, ilgili paylaşımın altına yorum yapmak yerine genel olarak son yapılan paylaşımın altına kümelendikleri görülmüştür. Takipçilerin; Açıköğretim Sistemini ve sistemin kurumsal sosyal medya ortamının özelliklerini tanıdıkça, tecrübeleri arttıkça, ilgili paylaşımın altına daha anlamlı yorumlar yapacakları öngörülmektedir.

Temmuz 2016 ve Şubat 2017 ayları içerisinde öğrenciler diğer aylara göre daha yoğun etkileşim kurmuşlardır. Bunun sebebi olarak, öğrencilerin sınavlar ve sorulara ilişkin paylaşımlara daha fazla ilgi göstermeleri ve dikkat çekmeleri olduğu düşünülmektedir. Takipçilerin ilgi, ihtiyaç ve beklentilerinin belirlenmesi ve bu konularda paylaşımlarda bulunulmasının, sosyal medya ortamının daha verimli kullanılmasını sağlayacağı öngörülmektedir. Kullanımlar ve doyumlar yaklaşımı çerçevesinde incelenerek öne çıktı̆ı belirlenen eğlence ve sosyalleșme boyutlarında doyum sağlayabilmek için sayfa paylașım 
İlgili sosyal medya hesabındaki beğeni artışının, daha çok kurumun diğer bilgi verme ortamı olan SMS gönderileri sonrasında gerçekleştiği belirlenmiştir. Sosyal medya ortamı kullanımı alışkanlığı oluştukça SMS paylaşımlarında azalma olacağı ve sosyal medya ortamının çok önemli bir bilgilendirme platformu olacağı öngörülmektedir. Kurumun oluşturacağı farklı bir destek ortamı mevcut sosyal medya ortamının destek amaçlı kullanımının önüne geçerek daha çok sosyal etkileşim kurma ve bilgi paylaşımı doğrultusunda evrileceği öngörülmektedir. Takipçilerin sosyal medya ortamında yapılan paylaşımların maksadını anlama noktasında tecrübesizlikleri ifade bırakma davranışlarına yansımıştır. Gündeme ilişkin beklentisini karşıayan paylaşımı "Beğen", beklediği konu ile ilgili olmayan paylaşımlara ise "Kızgın" ifadesi bırakmışlardır.

Bu araştırma sonuçları dikkate alınarak; yıllık düzeyde ve daha farklı araştırma problemleri ile öğrencilerin sosyal medya ortamlarını ne maksatla kullandıkları ve ne düzeyde doyum elde ettiklerine ilişkin çalışmalar çeşitlendirilirse daha görevsel sosyal medya ortamlarının geliştirilmesi ile daha etkili iletişim ve neticesinde etkileşim sağlanacaktır.

\section{Kaynakça}

Alikılıç, Ö., Gülay, G., ve Binbir, S. (2014). Kullanımlar ve Doyumlar Yaklaşımı Çerçevesinde Facebook Uygulamalarının İncelenmesi: Yaşar Üniversitesi Öğrencileri Üzerine Bir Araştırma. Iletişim Kuram ve Araştırma Dergisi, 1 (37).

AÖF. (2017). www.anadolu.edu.tr/acikogretim adresinden 25.03.2017 tarihinde alınmıştır.

Aydın, í. E. (2016). Üniversite Öğrencilerinin Sosyal Medya Kullanımları Üzerine Bir Araştrrma: Anadolu Üniversitesi Örneği. Selçuk Üniversitesi Sosyal Bilimler Enstitüsü Dergisi, (35), 373-386.

Bedir, A., ve Gülcü, A. (2016). Sosyal medya kullanımının üniversite öğrencilerinin akademik başarılarına ve tutumlarına etkisi. Erzurum Atatürk Üniversitesi Eğitim Bilimleri Enstitüsü Yüksek Lisans Tezi.

Erdoğan, İ. ve Alemdar, K. (2005). Öteki kuram: kitle iletişimine yaklaşımların tarihsel ve eleştirel bir değerlendirmesi. Ankara: Erk.

Erkek, S. (2016). Kamu kurumlarında sosyal medya kullanımı: sağlık bakanlığı örneği. Selçuk Üniversitesi Sosyal Bilimler Enstitüsü Dergisi, (35), 141-150.

Facebook Yardım. (2017). www.facebook.com/support/?ref=hc_global_nav adresinden 04.04.2017 tarihinde alınmıştır.

Fiske, J. (2003). İletişim Çalışmalarına Giriş. Çev. Süleyman İrvan. Ankara: Bilim ve Sanat Yay.• Çebi. Discursive Construction of Islamophobia in Anti-Minaret Referendum Posters in Switzerland.

IAB, (2011), "Türkiye İnternet Ölçümleme Araştırması", htttp_://www.iab-turkiye. org/files/newsletter/iab_newsletter-Mart_2011.pdf, Erişim tarihi: 25.09.2017.

Kaplan, A. M. ve Haenlein, M. (2010). Users of the world, unite! The challenges and opportunities of Social Media. Business horizons, 53(1), 59-68.

Kaptan, S. (1998). Bilimsel araştırma teknikleri ve istatistik yöntemleri. Ankara: Tekışık Web Ofset Tesisleri.

Karasar, N. (2012). Bilimsel Araştırma Yöntemi (24. Bask). Ankara: Nobel.

Katz, E. (1959). Mass communications research and the study of popular culture: Studies in Public Communication,, 2:1-6.

Küçükali, A. (2016). Üniversite Öğrencilerinin Sosyal Medya Kullanımı: Atatürk Üniversitesi Örneği. Bartın Üniversitesi iiBF Dergisi, 7(13), 531-546.

Küçükkurt, M., Hazar, Ç. M., Çetin, M. ve Topbaş, H. (2009). Kullanımlar ve Doyumlar Yaklaşımı Perspektifinden Üniversite Öğrencilerinin Medyaya Bakışı. Selçuk Üniversitesi Illetişim Fakültesi Akademik Dergisi, 6(1).

Mangold, W. G. ve Faulds, D. J. (2009). Social media: The new hybrid element of the promotion mix. Business horizons, 52(4), $357-365$.

Mayfield, A. (2010), What is Social Media, iCrossing, e-book, s. 6. http://www.au.af.mil/au/awc/awcgate/ifa/mayfield strat for soc media.pdf adresinden 02.10.2017 tarihinde erişilmiştir.

Sayımer, i. (2008). Sanal ortamda halkla ilişkiler. Beta.

Severin, W. J. ve Tankard, J. W. (2001). Communication theories: Origins, methods, and uses in the mass media. Pearson College Division.

Sezgin, S., Erol, O., Dulkadir, N. ve Karakaş, A. (2011). Bilgisayar ve Öğretim Teknolojileri (BÖTE) Öğrencilerinin Facebook Kullanım Amaçları ve Eğitsel Bağlamda Kullanımı Ille İlgili Görüşleri: MAKÜ Örneği. International Educational Technology Conference (IETC), İstanbul Üniversitesi, 25-27 Mayıs, İstanbul.

Smartinsight. (2018). www.smartinsight.com adresinden 25.01.2018 tarihinde alınmışttr.

Solmaz, B., Tekin, G., Herzem, Z. ve Demir, M. (2013). İnternet ve Sosyal Medya Kullanımı Üzerine Bir Uygulama. Selçuk üniversitesi iletişim fakültesi akademik dergisi, 7(4), 23-32.

Statisca. (2018). www.statisca.com adresinden 25.01.2018 tarihinde alınmıştır.

TUIK. (2018). www.tuik.gov.tr adresinden 25.01.2018 tarihinde alınmıştır.

UDH, 2018. Kamu kurumlarında sosyal medya kullanım rehberi, T.C. Ulaştırma Denizcilik ve Haberleşme Bakanlığı, Haberleşme Genel Müdürlüğü

http://afyonluoglu.org/news/kamu-kurumlarinda-sosyal-medya-kullanim-rehberi-taslak/ adresinden 15.10.2018 tarihinde alınmıştır.

Üçer, N. (2016). Kullanımlar ve Doyumlar Yaklaşımı Bağlamında Gençlerin Sosyal Medya Kullanımına Yönelik Niteliksel Bir Araştırma, Global Media Journal TR Edition, 6 (12), Bahar

Vural, Z. ve Bat, M. (2010). Yeni bir iletişim ortamı olarak sosyal medya: Ege üniversitesi iletişim fakültesine yönelik bir araştırma. Journal of Yasar University, 5(20), 3348-3382.

Yıldız, A., ve Demir, F. M. (2016). Üniversite Öğrencilerinin İnternet Ve Sosyal Medya Kullanım Amaçlarının Belirlenmesine Yönelik Bir Araştırma: Muğla Sıtkı Koçman Üniversitesi Örneği. Sosyal Ve Beşeri Bilimler Araştırmaları Dergisi, 1(37 Girişimcilik Özel Sayısı), 1836.

Weinberg, T. (2009). The new community rules: Marketing on the social web. O'Reilly Media, Inc.

Telli Yamamoto, G. ve Karamanlı-Şekeroğlu, Ö. (2014). Sosyal medya ve blog. İstanbul: Kriter Yayınevi.

| Kastamonu Eğitim Dergisi, 27(2), 2019| 